жүйелерге қойылатын негізгі талаптар, мұндай жүйелерді пайдалану және олардың сипаттамалары келтірілген.

Түйінді сөздер: танымдық радио, кең жолақты жүйелер, танымдылық.

\title{
Azbergen K.T.
}

Scientific superviser: Aitmagambetov A.Z.

Cognitiveness of ultra-wideband radio systems

Abstract. The article discusses methods to achieve a high degree of adaptation of ultrawideband systems to changing transmission conditions. The basic requirements for cognitive radio systems, the use of such systems and their characteristics are given.

Key words: cognitive radio, super wideband systems, cognitiveness.

\section{Сведения об авторах:}

Азберген Қарлығаш Тастанбайқызы, магистрант кафедры «Компьютерной инженерии и информационной безопасности» Международного университета информационных технологий.

Айтмагамбетов Алтай Зуфарович, профессор кафедры «Радиотехника, электроника и телекоммуникации» Международного университета информационных технологий.

УДК 004.03

\author{
Даирбаева C.A. \\ Международный университет информационных технологий \\ Алматы, Казахстан \\ Научные руководители: Синчев Б.К., Рысбайулы Б.

\section{ОПРЕДЕЛЕНИЕ ФУНКЦИОНАЛЬНЫХ ТРЕБОВАНИЙ К ИНФОРМАЦИОННОЙ СИСТЕМЕ МАГИСТРАЛЬНОГО ТРУБОПРОВОДА}

Аннотация. В статье рассмотрены функииональные требования к информационной системе магистрального трубопровода. Объектом исследования выбран нефтепровод Узень-АтырауСамара. В качестве примера разработан информачионный блок карты нефтепровода. Приведены основные требования к разрабатываемой системе, информационному обеспечению, безопасности и разграничению доступа, графическому дизайну.

Ключевые слова: информационная система, магистральный трубопровод, блок карть нефтепровода.

\section{Введение}

Появление новых технологий и повсеместное увеличение добычи нефти способствовало повышению уровня автоматизации технологических процессов в нефтяной отрасли и созданию принципиально новых информационно-управляющих систем, главная цель которых - обеспечение бесперебойной, надежной и эффективной работы магистрального нефтепровода [1].

Для расширения возможностей информационно-управляющих систем необходима разработка автоматизированного вычислительного комплекса, позволяющего контролировать изменения тепловых процессов и технологических параметров нефтепровода. Такие системы используют новейшие технологии, средства и математические методы с целью освобождения человека от участия в процессах получения, преобразования, передачи

International Journal of Information and Communication Technologies, Vol.1, Issue 1, March, 2020 
информации. Кроме этого, информационно-управляющие системы позволяют повысить производительность труда, улучшить качество технологического процесса и оптимизировать управление в целом. Разработка автоматизированного вычислительного комплекса невозможна без определения функциональных требований, предъявляемых к современным информационным системам магистральных трубопроводов.

Цель работы определить функциональные требования к разработке информационной системы магистрального трубопровода.

\section{Функциональные требования к информационной системе магистрального трубопровода}

В качестве объекта исследования выбран подогреваемый магистральный нефтепровод Узень-Атырау-Самара. Нефтепровод проложен с месторождения Узень до Атырауского нефтеперерабатывающего завода, дальше соединяется с системой нефтепроводов «Транснефти» в направлении Самары. Трубопровод специально подогревают в процессе перекачки высоковязкой и высокозастывающей нефти из Жетыбай-Узеньской группы месторождений. Протяжённость нефтепровода составляет более 1380 км, на территории Казахстана - 1232 км.

Отрезок между двумя головными насосными станциями (ГНС) с расстоянием, расстояние между ними 1230 км. Данный отрезок делится на 5 участков. На каждом из участков расположены промежуточные насосно-тепловые станции (ПНС), на которых датчиками будут измеряться тепловые характеристики протекающей высоковязкой нефти, а также вычисляться другие характеристики - температура окружающей среды, теплоемкость, теплопроводность, теплоотдача, объемный вес грунта, глубина прокладки труб. На ГНС также установлены датчики, которые измеряют температуру, давление, расход, скорость движения жидкости и температуру подогрева [2].

Для определения функциональных возможностей информационной системы, необходимо провести анализ требований к разрабатываемой системе, информационному обеспечению, безопасности и разграничению доступа, графическому дизайну и прочие. Функциональные возможности разрабатываемой системы:

- Ввод данных.

- Вывод результатов и графика программы алгоритма расчета (математическая модель).

- Отображение данных.

- Отображение Карты нефтепровода, а именно участка между двумя ГНС в районе от Узень до Атырау.

- Обеспечение динамического представления данных (в режиме реального времени).

- Формирование, экспорт отчетов.

- Управление оборудованием (двигатели насосов, задвижек и клапанов или нагревательных элементов).

- История диагностики работы оборудования.

- Обратная связь со специалистами предприятия.

Пользовательский интерфейс приложения должен обеспечивать наглядное, интуитивно понятное представление структуры размещенной на нем информации, быстрый и логичный переход к разделам и страницам. Навигационные элементы должны обеспечивать однозначное понимание пользователем их смысла: ссылки на страницы должны быть снабжены заголовками, условные обозначения соответствовать общепринятым.

Требование к информационному обеспечению подразумевает использование для реализации функциональной части программные языки PHP, HTML. Кроме этого, допускается использование различных фреймворков.

Разрабатываемая система должна предусматривать соблюдение требований к безопасности и разграничению доступа. Так как информация является закрытой, доступ может быть предоставлен только сотрудникам Предприятия.

International Journal of Information and Communication Technologies, Vol.1, Issue 1, March, 2020 
Пользователи могут авторизоваться на главной странице с помощью специальной формы авторизации. Функциональные возможности модуля управления личным кабинетом:

1. Модуль должен предоставлять вход в систему (аутентификация) через логин и пароль.

2. Поиск объекта по логину из таблицы базы данных MySQL.

3. Вывод результатов по данным запроса.

4. Доступ к различным данным, типам информации.

Завершающим критерием разрабатываемой системы являются требования к графическому дизайну. Разрабатываемая web-система должна иметь корректное отображение при расширении экрана 1024х765 точек и выше, при цветности Hi Color 16 bit (65536 цветов) и выше. Дизайн должен быть выполнен с использованием языка HTML и CSS, а также по принципам UI/UX.

Необходимо создать структуру (шаблон) сайта, состоящего из следующих элементов:

1. Навигационное меню и header всегда должны быть на одном месте независимо от страницы сайта.

2. Информационные блоки:

- Блок карты нефтепровода.

- Блок таблицы значений данных насосно-тепловых станций и участков (промежуточных-насосных станций) магистрального нефтепровода.

- Блок графика полученных данных.

- Блок математической модели.

3. Блок контроля оборудования.

В качестве примера был разработан блок карты нефтепровода, представленный на рисунке 1. На карте отображены две ГНС «Узень» и «Атырау», а также 5 ПНС. При нажатии на метки головных насосно-тепловых и промежуточных тепловых станций отображается текущая информация о технологических параметрах магистрального трубопровода.

Данные также можно отобразить в виде графиков и таблиц с возможностями поиска, сортировки, вывода расширенной строчной таблицы по каждому уникальному идентификатору. Полученные результаты можно сформировать, экспортировать в виде отчетов в форматах PDF и XLSX.

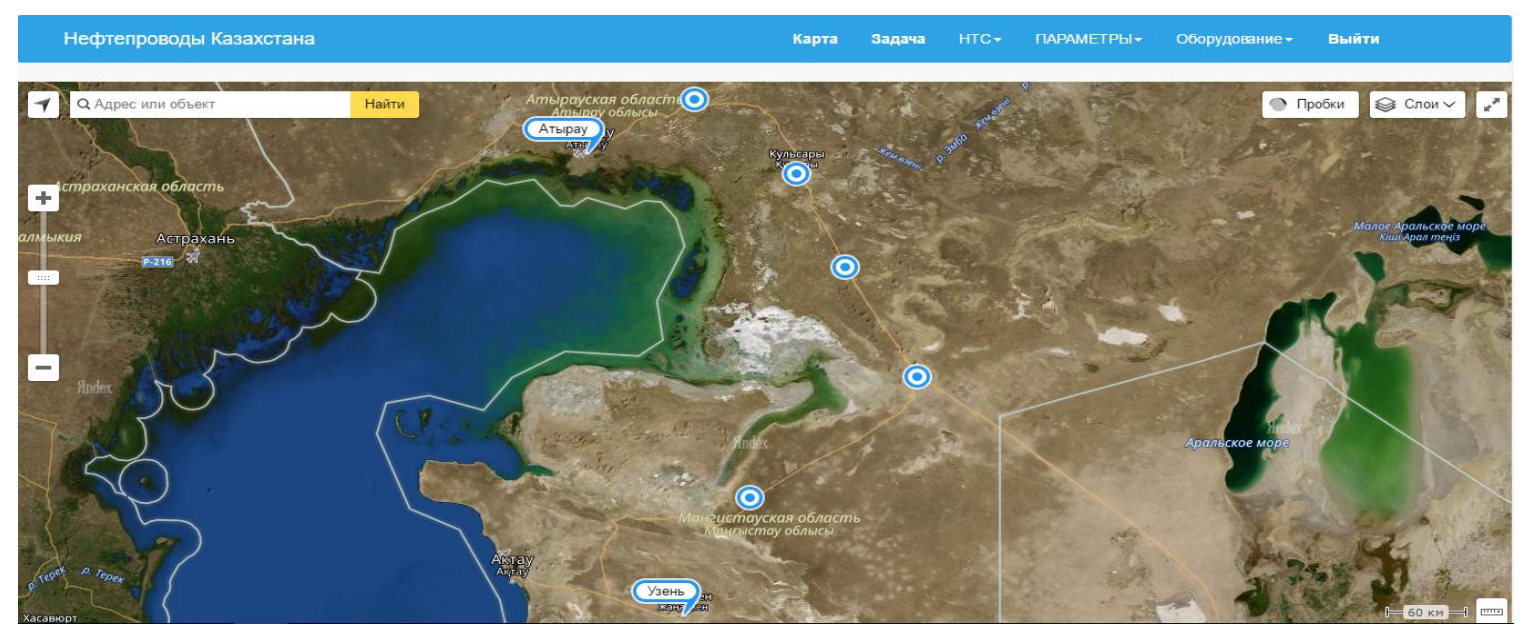

Рисунок 1 - Блок карты нефтепровода

\section{Заключение}

Таким образом, в результате определения функциональных требований к информационной системе магистрального нефтепровода поставлены задачи дальнейшего проектирования системы. Конечный программный продукт может быть внедрен в систему 
нефтяной промышленности, а именно в предприятия насосно-тепловых станций и нефтяных магистралей.

Разрабатываемая информационная система позволит фиксировать параметры температуры, тепловых и общих характеристик нефти, труб и грунта, контролировать процесс перекачки нефти, управлять оборудованием ГНС, обеспечить выявление и устранение неполадок оборудования.

\section{ЛИТЕРАТУРА}

1. Даирбаева С.А., Даирбаев А.М., Синчев Б.К., Рысбайулы Б.Р. Исследование информационных систем транспортировки нефти магистральным трубопроводом // Вестник КазНУ. Серия математика, механика, информатика. - №2(102). - 2019. - С. 56-68.

2. Dairbayeva S.A. Automatic Process Control System of Main Pipeline // Вестник КазНУ, Серия математика, механика, информатика. - №1(88). - 2016. - С. 88-94.

\section{Даирбаева C.A.}

Ғылыми жетекшілері: Синчев Б.К., Рысбайулы Б.

Негізгі басқару ақпараттық жүйесінің функциялық талаптарын анықтау

Андатпа: Мақалада магистральдық құбырлардың ақпараттық жүйесін дамытуға қойылатын функционалдық талаптар талқыланады. Зерттеу нысаны Өзен-Атырау-Самара мұнай құбыры болды. Мысал ретінде, құбырлар картасының ақпараттық блок жасалды. Әзірленген жүйеге, ақпараттық қолдау, қауіпсіздік пен қол жеткізуді басқаруға, графикалық дизайнға қойылатын негізгі талаптар келтірілген.

Кілт сөздер: ақпараттық жүйе, магистральдық құбыр, мұнай құбырларының картасы.

\section{S.A. Dairbayeva \\ Scientific supervisers: Sinchev B.K., Rysbaiuly B.}

Determination of functional requirements of the main pipeline information system

Abstract. The article discusses the functional requirements for the main pipeline information system. The object of study was the Uzen-Atyrau-Samara oil pipeline. As an example, the pipeline map section has been developed. It was given the basic requirements for the system, information support, security and access control, graphic design.

Key words: information system, main pipeline, section of the oil pipeline map.

\section{Сведения об авторах:}

Даирбаева Сабина Алипбаевна, докторант $\mathrm{PhD}$ кафедры «Информационные системы» Международного университета информационных технологий.

Синчев Бактыгерей Куспанович, д.т.н., профессор кафедры «Информационные системы» Международного университета информационных технологий.

Рысбайулы Болатбек, доктор физико-математических наук, профессор кафедры «Математическое и компьютерное моделирование» Международного университета информационных технологий. 